\title{
"I'm Here and I Am Queer". Queer Teacher Identities in ELT. A Colombian Study
}

Primer semestre de 2021 - pp. 91-106 Segunda época

N.

\author{
“Estoy aquí y soy \\ queer". Identidades \\ de maestros queer \\ en ELT. Un estudio \\ colombiano
}

\author{
"Estou aqui e sou \\ queer". Identidades \\ de professores \\ queer em ELT. Um \\ estudo colombiano
}

* MA degree in Applied Linguistics to TEFL. Language teacher and teacher educator Artículo recibido who currently works at Universidad Distrital Francisco José de Caldas, (Bogotá, Colombia).

Correo electrónico: dfubaquec@udistrital.edu.co

** H. PhD in Education. Director of the Doctorado Interinstitucional en Educación (ELT Education Major) at Universidad Distrital Francisco José de Caldas (Bogotá, Colombia).

Correo electrónico: hacastanedap@udistrital.edu.co

Ubaque-Casallas, D. y Castañeda-Peña, H (2021). "I'm Here and I Am Queer." Queer Teacher Identities in ELT. A Colombian Study. Folios, 53. https://doi.org/10.17227/folios.53-11291 


\section{Abstract}

There has been a significant upsurge of research regarding gender and its connection to teacher professional identity. In this paper, we adopt a decolonial stance to document how the queer identities and pedagogies of two teachers of English resist colonial notions of being and doing within the English Language Teaching (ELT) setting. This study regards gender identity as a political mechanism that has been structured in terms of relations of domination. In addition, it explores these structures by employing the coloniality of being as the axe to analyse gender categories in the ELt field. To do this, we used a narrative approach to voice personal constructions of gender and gendering discourses about queer identities and pedagogies. Findings suggest that queer teachers of English construct and negotiate their identities in their professional settings and their own performativities in the classroom shape their own epistemologies and teaching practices.

\section{Keywords}

English Language Teaching; queer identity; professional identity; pedagogy

\section{Resumen}

Se ha dado un aumento significativo de la investigación sobre el género y su relación con la identidad profesional docente. En este artículo, adoptamos una postura decolonial para documentar cómo las identidades y pedagogías queer de dos profesores de inglés se resisten a las nociones coloniales de ser y hacer dentro del entorno de la enseñanza del inglés (ELT). Este estudio considera la identidad de género como un mecanismo político que se ha estructurado en términos de relaciones de dominación. Además, explora estas estructuras empleando la colonialidad del ser como eje para analizar las categorías de género en el campo de elt. Para hacerlo, utilizamos un enfoque narrativo para expresar construcciones personales de género y discursos de género sobre identidades y pedagogías queer. Los resultados sugieren que los profesores queer de inglés construyen y negocian sus identidades en sus entornos profesionales y sus performatividades en el aula dan forma a sus propias epistemologías y prácticas de enseñanza.

\section{Palabras clave}

enseñanza del inglés; identidad queer; identidad profesional; pedagogía

\section{Resumo}

Houve um aumento significativo nas pesquisas sobre gênero e sua relação com a identidade profissional docente. Neste artigo, adotamos uma postura descolonial para documentar como as identidades e pedagogias queer de dois professores de inglês resistem às noções coloniais de ser e fazer dentro do ambiente de ensino de inglês (ELT). Este estudo considera a identidade de gênero como um mecanismo político que se estruturou em termos de relações de dominação. Além disso, explora essas estruturas a partir da colonialidade do ser como eixo de análise das categorias de gênero no campo do etr. Para fazer isso, usamos uma abordagem narrativa para expressar construções pessoais de gênero e discursos de gênero sobre identidades e pedagogias queer. Os resultados sugerem que os professores de inglês queer constroem e negociam suas identidades em seus ambientes profissionais, e suas performatividades em sala de aula moldam suas próprias epistemologias e práticas de ensino.

\section{Palavras chave}

ensino de inglês; identidade queer; identidade profissional; pedagogia 


\section{Introduction}

Decolonizing gender in the ELT field seeks, more than addressing colonial structures of being that have been constantly both marginalized and understood from traditional hierarchies of Western/North dominant knowledge, to better recognize that such colonization exists and has occurred at three levels: (i) the gendered being, (ii) knowledge about gender and (iii) the exercise of power of some genders over others. So, we consider that decolonizing gender in the ELT field is not just about looking for colonial structures in the being, but it also involves examining those colonial structures at the levels of knowledge and power in a gender key in those where the 'extermination' of gendered identities occurs in a customary way.

We believe that areas of ELT such as the initial education of teachers of English, the professional development of in-service teachers, the particular teaching of general English, and other fields that do not think of gays, lesbians, transgender, and intersexed language teachers and students, are still in need of exploration. Aligned to this interest, some scholars have contributed to understanding gender, in a more local context, by exploring how pre-service and in-service teachers develop as professionals (Fajardo-Castañeda, 2014), as well as how queer English language teacher identities in the ELT field are constructed (Lander, 2018).

Despite this inquiry, we believe the identities of queer teachers of English must be revisited taking into consideration their vast plurality. Consequently, due to a not new but emerging decolonial stance, some scholars have tried to approach this logic "from below and from within" (Escobar, 2010, p. 393) to dismantle:

[...] relations of power and conceptions of knowledge that foment the reproduction of racial, gender, and geopolitical hierarchies that came into being or found new and more powerful forms of expression in the modern/colonial world.

(Maldonado-Torres, 2011, p. 1)

With this purpose, we acknowledge that there are multiple forms of oppression (Battiste, 2013), such as in race, gender, ethnicity, class, language (Pennycook, 1998); that are still reproduced within the ELT field that demand new perspectives to understand the complex dynamics that language teaching entails. Among these oppressions, gender continues to be an essentialist bias dimension of teacher identity that still appears as a relational category mediated by the binariness of the biological terrain (Butler, 2004). Therefore, having established that the queer identity of ELT teachers is a relevant category for the ELT field, this study is interested in installing the decolonial spirit in matters of identities to understand the multiple and diverse possibilities of being. This aim has no other purpose than interrupting the idea of disembodied identities the ELT field has kept as a universal signifier of the West's global model.

\section{Theoretical foundations}

\section{Coloniality of being}

The emergence of the concept coloniality of being responds to "the need to thematize the question of the effects of coloniality in lived experience and not only in the mind" (Maldonado-Torres, 2007, p. 242). This ontological understanding puts forward a different way of contesting the already old ideas and practices between the dominant and the dominated (Quijano, 2000a). For this study, this concept is relevant as we deal with fixed and normative notions of identity that have placed individual identities within a generalized understanding of being. Grosfoguel (2008) clearly links this idea with coloniality:

European patriarchy and European notions of sexuality, epistemology, and spirituality were exported to the rest of the world through colonial expansion as the hegemonic criteria to racialize, classify and pathologize the rest of the world's population in a hierarchy of superior and inferior races. (p. 7)

Undoubtedly, identity has been part of the architecture used to classify what is understood as being. In addition, for decolonization, all concepts need to be conceived as invitations to dialogue and not as impositions (Maldonado-Torres, 2007). Our objective in this article is not to oppose, but to enrich 
several definitions of teacher identity that have been assigned in the ELT field. Among some definitions we can find teacher identity described as a "discursive struggle" (Trent, 2013, p. 428); "a certain kind of person in a given context" (Gee, 2000, p. 99); or even as a fluid, dynamic, and ongoing developmental process (Mockler, 2011). Even though we might agree with these definitions, we also believe that from the colonial perspective of being, the identities of teachers of English can be best established if the notion itself is framed within the challenges of overcoming colonial forms of 'being with' as we are facing a contemporary mechanism of coloniality within the ELT field that either inherited or not has constructed teachers as both owners of generalized knowledge and essentialist being within a global canonical narrative. Consequently, we mean to interrupt the colonisation (Lugones, 2010) teachers of English have been bound by. As other possibilities of identity have not been heard / given voice, we propose to acknowledge that the colonization of gender identity has departed from this ontological subalternization in which gender identity has been invisibilized.

\section{Queer identity}

Even though we regard the concept of identity as a remnant pattern of power, we acknowledge that identity is key to moving away from notions of the same concept where, ontologically speaking, this has served to label certain populations and to subject them to certain performances of gender and heterosexuality (Connell, 2009). For instance, it has been customary for any educational system to reinforce normative performances regarding gender varieties. Commonly, students who are products of our society "bring heterosexist attitudes with them into the classroom" (Gates, 2011, p. 73) that are contested or reassured depending on the classroom dynamics regarding this subject.

Unfortunately, due to the oppressive power of cultural and education systems:

Educators expend energy hiding or protecting themselves from the prejudice and ignorance of a homophobic community. In a society committed to social justice, gay and lesbian educators would not be required to sacrifice their sense of self-integrity to remain in their chosen profession. (Griffin, 1992, p. 195)

This sacrifice regarding identitarian performances has made teachers choose between 'coming out' or 'remaining in' in their classes. We argue that performing aligned to one's own gender identity is linked to concepts such as good teaching or teacher identity inasmuch as it comes from the identity and integrity of the teacher, and good teachers have integrated identities and translated from their sense of self in the classroom (Palmer, 2007).

Taking this into consideration and in order to embrace different and multiple ways of being, this study understands the term queer, as "a broad term for a wide range of non-normative sexual and gender identifications" (Gray, 2016, p. 225). This also resonates with underpinning understandings that claim that "identity politics may be permanently troubled" (Wilchins, 2004, p. 152) and that "attempts to present any identity as a foundation will, inevitably or inadvertently, reinforce the existing binary structures of sexual, gender, and libidinal relationships" (Spargo, 2004, p. 68). Such understandings sweep away any possibility to continue categorizing queer identities within heteronormative configurations. So, if the identities of Colombian teachers of English are mapped from those who perform them, we could, as Nash (2010) suggests, shed light:

\section{[...] on the possibilities and potentialities for lives lived in incongruent and conflicting relationships with normative systems of meaning - neither within nor without - but as a form of fluidity; a mobile instability in experiences, behaviours, and practices of the self. (p. 132)}

\section{Teacher identity}

We regard teacher identity as the being that informs doing (Taylor, 1989) and includes the "narratives about individuals that are reifying, endorsable, and significant" (Sfard \& Prusak, 2005, p. 16). Therefore, as we want to go beyond an understanding of identity where it is seen as "the link between professional 
identity and professional action" (Watson, 2006, p. 510), we refer to teacher identity as a personal, self-performed category of teaching that extends from the past to the future, but that is constructed and situated in the self along with one's own life history and stories.

As we are interested in presenting teacher identity from the locus of queer teachers, we consider it is worth saying that to decolonize teacher identity we must situate teacher identity as involving crises that lead to transformations (Meijer, de Graaf, \& Meirink, 2011) to embrace the fact that teacher identity is a fluid, dynamic, and ongoing developmental process influencing and being influenced by a multitude of factors (Mockler, 2011). So, to understand local teacher identities, there must be a decolonial spirit that can contest coloniality of being operating within ontological and epistemological conceptions of teacher education. Such an attitude "demand[s] responsibility and the willingness to take many perspectives and [the] points of view of those whose very existence is questioned and produced as insignificant" (Du Bois, 1999, p. 262).

Therefore, teacher identity should challenge colonial ways of thinking and acting. The starting point of decolonization is not a rejection of colonialism but the acknowledgement of existing structures of domination (Hooks, 1990). This, we believe, does not mean to replace the dominant with the marginalized (Sharma \& Agmad Mir, 2019) but to position an epistemic shift in which the subaltern speaks and is heard. With this, we consider that gay teacher narratives can help decolonize, re-imagine, and rearticulate known teachers of English ontologies within myriad gender dimension(s).

\section{Gender}

We regard gender as a remnant of coloniality as well. As such, much of what has been said about gender is well tailored through cultural discourses endorsed by means of language use (Mayer \& Wodak, 2009). These discourses have imposed, wittingly or unwittingly, labels, and categories that have perpetuated gender as the social behaviours, expectations, and attitudes that are linked to being male and female
(Litosseliti, 2006). However, these features that are indeed cultural constructions have been socially determined by a long history of validation of the oppressing social gendering and gendered discourses reproduced by the logic of coloniality and modernity made evident through Eurocentric discourses imposed upon Latin America / Colombia.

We consider that, when it comes to language teaching, Colombian teachers of English and their gender identities have been somehow documented but barely heard. Methodologically speaking, there has been a poststructuralist approach to comprehend gender and identities, but this seems to have employed an apparent essentialist understanding of the other that, in the end, might be sustaining the reproduction of colonial impositions of being.

This notion of the other ${ }^{1}$, for us, reflects an understanding of knowledges that differs from the Western tradition and promotes the comprehension of multiple modes of being that subvert the heteronormative and fixed categories individuals, not just teachers, have been tied to.

Bearing the aforementioned in mind, we think we must refer to the coloniality of gender as it "[...] lies at the intersection of gender/class/race as the pivotal construct of the capitalist world system of power" (Lugones 2010, p. 746). With this, we argue that gender is a colonial construct of dispossession that needs to be inspected within the ELT field. Therefore, to complement this categorization from another perspective, we are aiming to make visible the artificial, constructed nature of 'subalternization' thinking (Mignolo 2011, p. 72) that has positioned gender identities among ELT teachers as a Western category and mechanism of power. Aligned to this, we also agree with Lugones (2008) who argues that

Understanding these features of the organization of gender in the modern/colonial gender system-the biological dimorphism, the patriarchal and heterosexual organizations of relations-is crucial to an understanding of the differential gender arrangements along "racial" lines. Biological dimorphism,

1 Within deconolianism there are decolonialisms. As a result, there exist different understandings of otherness (Mignolo \& Walsh, 2018). 
heterosexual patriarchy is all characteristic of what I call the "light" side of the colonial/modern organization of gender. (p. 2)

Consequently, since decolonizing gender is a practical task embedded in our own epistemological interest as researchers, we believe we must promote "a lived transformation of the social" (Lugones, 2010 , p. 746) by voicing up those who have been dispossessed but also by capitalizing on the importance of listening to them counter their historically voiceless status.

\section{Context of the study and participants}

The study was conducted in a private but non-profit English language teaching institution in Bogotá, Colombia. Lea and Duncan (not their real names) who are teachers of English and whose ages are between 20 and 45 years old were invited to participate in a six-month study in order to collect their experiences regarding their queer performances in the EFL classroom. Lea and Duncan were invited due to their identities as queer teachers of English and as they were relevant to the interest of the study (Miles \& Huberman, 1994). Their participation in the study was not just limited to providing the experiences, but they participated in the identification of meaningful events of their own narrations.

\section{Narrative inquiry as a research methodology: seeking a decolonial nexus}

Rodríguez (2016) considers that the methodological issue is important in the decolonization process. Therefore, this study takes on narrative inquiry as a research methodology in which the narrator or protagonist is an active agent not a dupe (Elliott, 2005) to thus delink from conceptions of identity as a remnant of colonial paradigms. We opted for this methodological route to "attend to individuals' lives remaining attentive to the larger contexts and relationships within which lives are nested" (Clandinin, Cave, \& Berendonk, 2017, p. 91). In adopting narrative inquiry, we commit to both, a narrative ontology that acknowledges experience as continuously interactive (Dewey, 1938) and a personal research epistemology where the narrative is a tool to have "the certitude that the subaltern can speak” (Mendoza, 2016, p. 112).

By adopting narrative inquiry, as research methodology, we consider we can imagine a relationship with Duncan and Lea that goes beyond coercion and subjugation. This methodological decision commits our own research to identify what kinds of voices we are expressing in order to dismantle the logic of coloniality that is "problematically enlivened through educational research" (Patel, 2019, p. 12). Accordingly, we commit to promoting an epistemology that emphasises that "learning and knowledge are never placeless" (p. 61) and in so doing can address and highlight the tensions that exist in colonial structures of knowledge production (Mendoza, 2016).

\section{Data construction and analysis}

We share the view that narrative is a way of accessing knowledge (Domínguez \& Herrera, 2011). Consequently, we will not refer to a process of data collection in this manuscript but to the process of data construction. In this respect, such construction started by having Duncan and Lea participate in a number of three oral interviews that were later transcribed. This decision was made as they were invited to locate and further comment on some events, we had considered relevant to be inspected. In doing this, we aimed at creating an intersubjective link in which their narrations could only voice a particular and unique story. In fact, this sort of procedure also allowed Lea and Duncan to see whether our representation and interpretations of their stories conveyed some of the meaning they intended to convey.

This methodological decision was grounded on a decolonial doing in which our decolonial action was intended not to follow any traditional research stage, but to work for a communal contemplation, alternative conversation, and a configurative reflection (Ortiz Ocaña \& Arias López, 2019) of the experiences we tried to understand. Consequently, we consider that when Lea and Duncan enter into 
a conversation not just in the interviews, but also in their commenting of our interpretations, our decolonial doing becomes more personal, "a matter not contemplated by Euro-centered intra-European hermeneutics and their corresponding methodological proposals with universal claim " (Borsani, 2014, p. 162). As a result, the traditional methodological assumptions in which participants can just be enunciated in the language of the West (Haber, 2011) are broken.

Therefore, we analysed the narratives reported here not just by reconstructing facts and experiences, but by listening to the experiences that, as we see them, create a sense of what has been dispossessed. With this, we do not mean to promote any universal truth that might emerge from narratives but we do want to speak about Lea and Duncan's other knowledges' as narratives possess a given transformative character that legitimizes different ways to configure reality and to relate to it. The aforesaid is what we name as data construction.

It is worth noting here that, although the nature of data reported in this study is completely narrative, excerpts used hereafter to construct the corpus of the study are seen as events. On this, we approached narratives by attempting to connect incidents into sequences of events that can shed some light onto how Duncan and Lea understand the multiple possibilities of fostering a personal positioning regarding gender and identity. Consequently, we reached narratives by detaching ourselves from the typical narrative analysis that in most of the cases ends up in epistemological extractivism; instead, we analysed narratives, methodologically speaking, by engaging in an inquiry to present other possible interpretations of identity. In short, what Lea and Duncan shared, our act of listening as researchers, and the construction of the meaning of participants' experience is what we understand as narrative knowledging (Barkhuizen, 2011).

\section{Findings}

The following analysis presents the narratives of two queer teachers of English. These narratives reflect their lived experience and personal discourse(s); this is why, not only will the analysis of the narratives articulate with the theory, but the narratives will also be heard taking into consideration that those who speak are the ones who possess the other knowledge we are interested in documenting. Nevertheless, it is worth noting here that these narratives were partially translated from Spanish to English after reported. Since they were the result of our engaging in an alternative conversation (Ortiz Ocaña \& Arias López, 2019) with Lea and Duncan; their experiences configure a relational meaning we tried to convey when translating.

\section{Lea's experience(s)}

Lea is a teacher of English who mainly identifies herself as queer. For Lea, being queer means feeling free to express herself and talk about her love live freely. However, she is not that open in class since she feels it could jeopardize her job as a teacher of English. This feeling has led her to "walk a constant line between safety and honesty" (Kissen, 1996, p. 16), making her construct and choose between dual identities. As far as this study is concerned, it is in this logic of duality that we can find colonial notions of being within the Colombian ELT classroom.

The aforementioned logic in which culture and structure of the modern world-system oppress who Lea really is, is what has been described as the coloniality of being (Maldonado-Torres, 2017). Using this concept of coloniality, we approach Lea's experience as a teacher of English. Lea, by identifying herself as queer, positions her own ontology as something that is informed by what she believes in. In the following excerpt, we can find her unique identification with queerness:

For me, queer is simply everything that is not heterosexual because I cannot define my identity as a lesbian since it does not fit there, or as bisexual, because I do not believe either very well in matters of gender marked as a man and woman, but for me there are other things in the middle or beyond the labels and so queer is like an invisible category, as it is a category to indicate that I am not hetero but it is very difficult to identify specifically who I am and that is why I like it very much. 
As for Lea's identification as queer, she marks her disagreement with the binary conception of gender. We consider it is in this discordance that Lea tailors other categories that go beyond the normative labels. In fact, she puts forward her own identity by emphasizing that she cannot identify herself with existing categories that fall short in determining who she is. Moreover, the category of queer is invisible and allows her to choose who she wants to be. However, as Lea moves in a Western-based environment, she seems to adopt the term queer with a universalist meaning. It becomes evident, for us, that no matter how she conceptualizes her own experience, it is difficult to separate herself completely from the traditional structures of society.

Since Lea contends there are many more possibilities between /other than being a man or a woman, identifying herself as queer restores the ontological-agency removed from her by the logic of the modern world-system. Nonetheless, as Lea refers to an invisible notion of being queer, we believe, it is important for us to delve deeper into this idea as in fact, it is an agentive form that should not be seen negatively but prospectively.

For example, we are seeing families in the class and I make my family trees with trans artists with drag people and I do not say this specifically to the students, but simply put them as an attempt to naturalize different identities and do it to show them, to simply make them visible. If you ask me ... or there is always that person who knows what is happening and is like "yes teacher, I saw that you put this person from gay groups", I feel I can use woman for adjectives a trans girl, or a drag girls because in addition its performativity [sic], using the word brings more options in terms of description of adjectives and also in terms of sport activities. We speak about able and disable bodies, then I put many things that have to do with the Paralympics to see different types of corporalities [...] I do this to naturalize, to make visible how different things exist. This is what I was saying, beyond identity, there is a whole social construction.

For Lea, there are multiple forms of being that are imperceptible but that can be visible through classroom discourses and activities. In this respect, we consider Lea is naturalizing the notion of difference as her queer identity is born between the ontological and epistemological tensions that she brings from her own life-story. It is important to note here that her narrative, apart from describing what occurs, also expresses and contains emotions, thoughts, and interpretations, thereby she places emphasis on the uniqueness of each event rather than on common characteristics (Bruner, 1987), heteronormative ones, others individuals might be familiar with. However, we sense Lea's queerness is composed of performances, beliefs, and notions of self that are rooted in the concept who I am is what I do.

Lea's performance in class allows her to enact what she believes in. In a certain way, she comes out and reveals her queerness by simply neutralizing what she considers has been tied to identity. Interestingly, her use of language reflects an expression of resistance against a logic that obscures students' understanding of the other and that without a doubt put a strain on hegemonic power structures where sexual, gender, and racial hierarchies of the modern/colonial capitalist/patriarchal world-system (Grosfoguel, 2005) are rooted. Importantly, since "language teaching contexts are not exempt from the responsibility of incorporating the gender perspective to help educational institutions battle gender inequities" (Mojica \& Castañeda-Peña, 2017, p. 140), Lea's attempt to disrupt fixed power structures becomes a pedagogical/ personal act of resistance that reinforces the importance of decolonizing gender as a practical task (Lugones, 2003).

Accordingly, Kumaravadivelu (2012) argues that language can work from an ideological perspective "to express a particular point of view to achieve a particular goal" (p. 25). Although this view of language also recognizes that "language is tied to power and domination" (p. 25), we believe that Lea's language choice reflects an ideologically grounded decision that is shaped by her queerness. In the following excerpt, we address Lea's ideological use of language more in detail. 
One thing that seems magical to me about English is that there is no [grammatically marked] gender like in Spanish. If I know that we are going to be talking about couples or families, the first concept I teach them is - significant other - with this, I can talk openly about my relationship, and in case there is someone who is in the closet, they can talk about their significant other without using any gender. Doing this allows certain performativity of what it is to leave the closet, or without feeling obligated which happens many times. For example in the VIP tasks where students choose a very important person to talk about, they say - I am going to choose my partner - then I tell them -choose your boyfriend or girlfriend, No matter who- I mention the word boyfriend or girlfriend because it seems important to highlight that it is possible.

Through language, Lea builds a personal yet collective discourse in which she can perform, discursively speaking, her queerness. The excerpt above makes explicit Lea's language choice to build a bridge for those who are 'in the closet' and might be afraid of disclosing their queer identities. We believe Lea's attempt to restore students' self-identification is a very meaningful onto-epistemological attempt to battle a dimension of coloniality in which power aims to keep subalternity as a condition usually constructed by means of discourse formations (Quijano, 1992). Arguably, Lea's performing is, to a large degree, an extension of a given queer but self-constructed pedagogy which has the purpose of interrupting "familiar patterns of thinking" (Sumara \& Davis, 1999, p. 192) in her students.

In closing Lea's experience, it is appropriate to note that Walsh (2009) describes the familiar dimension of the coloniality of power as it is founded on a racialized hierarchy and on the assumption of natural superiority. Nevertheless, as this dimension of coloniality has imposed ideas of inferior (queer) and superior (heteronormative) identity on people, it is not surprising that both students and teachers of English, feel certain oppression to 'come out'. What Lea does as a teacher of English aims to fragment set and fixed discourses and mental categories students have and that, without a doubt, end up perpetuating certain systems of meaning.
Having explored Lea's narrative, we consider necessary to hear from an individual and a professional whose experience can shed more light onto non-colonial matters of gender and teacher identity, relevant for the Colombian field.

\section{Duncan's experience}

Duncan is a teacher of English who identifies himself as queer. For him, being gay is not out of the ordinary, yet he considers that his identity as a gay teacher of English plays a huge role in his performing in class. For him, who he is, at times, makes students take some time to get to know him due to the fact he does not conform to what they expect of a teacher. In fact, this identity disclosure is quite interesting as research has shown that many teachers choose to disclose their identity to some teachers, or to all teachers, but choose to remain closeted with students (Hooker, 2010). The following excerpt aims to describe Duncan's particular position:

The first weeks the students suffer getting me because I am myself as you said from the beginning, you know they do not understand many things, I think that as I am, as such, let's remove the label, Duncan as such is a very complex figure because I am a person that I have been through a lot of things, I have learned a lot, I am a mess, yes I am! [...] when I am in the classroom I am very aware that I am there because I chose it because I am happy doing it and I have somehow or another [sic] I have learned to know a lot, I am still doing it but I have learned to know a lot and on that journey of the life of self-discovery; for me, there is no point in being a teacher if you are not sincere if you are not authentic. Now, about the gay story, was it what led me to become a teacher? Did it have to do with being gay? No. I always wanted to be a teacher, now as gay, as a gay man, I am also weird! but I also have it clear, it is very complex because at the sexual level I know that I like guys, [...] at the gender level I like to keep it masculine but let's say when you are gay you learn a lot about all of yourself including your masculinity.

For Duncan, the kind of professional he discloses in the classroom is who he is. Although coming out might make teachers look powerless and without 
agency (Ferfolja, 2009), coming out, as we regard it, allows teachers to exercise their own epistemological and ontological defiance. Interestingly, Butler (1990) provides a very valid argument by claiming that "norms might be inhabited differently because sometimes the very conditions for conforming to the norm are the same as the conditions for resisting it, conforming and resisting become a compounded and paradoxical relation to the norm" (p. 217). Thus, we consider Duncan's performance in class as disobedience that for him, consciously or unconsciously, represents reclaiming who he is and what good teaching is.

Regarding good teaching, Western/Northern notions have limited it to those "practices or behaviours positively associated with student outcomes" (Hanson, Paulsen \& Pascarella, 2016, p.738). However, thanks to Duncan's experience we can claim that good teaching is also about understanding the tensions inherent in being queer in the classroom and 'queering' the classroom, as Thompson (2004, p. 273) calls it. For him, songs, comments, images help him assert his own identity as a teacher. The following excerpt presents Duncan's narration of what he considers exposes his queerness.

Let's say that what screams first that I am gay is the music, I always play music in my classroom because I am a person who gets bored, so I try to play music to entertain myself and the students, but I think I do a very good selection of music, but when you look at the selection of music and there are videos that are iconically very gay, they are among disco, pop, also the slightly visual design of the visuals that I bring, I am very visual I try to put a little dedication to that and I sometimes bring visual things [...] I am gay the very first day, but if I feel that it is more comfortable for them once I tell them. I think that at the end of the day the most beautiful thing of all classes is that we know why we are there.

Through music, in Duncan's words, he comes out in front of his students. Nonetheless, we consider coming out is just a term to position the self as a coherent and recognizable subject (Butler, 2004) that in most cases goes in opposition to the norm and becomes a political act. It is worth noting here that although sexual identity categories can also be read as "instruments of regulatory regimes" (Butler, 1990, p. 13), refusing to come out can be read as conforming to those gender arrangements that have "introduced many genders and gender itself as a colonial concept and mode of organization of relations of production, property relations, of cosmologies and ways of knowing" (Lugones, 2008, p. 186).

As a matter of fact, Duncan's own queer performance in his classes echoes Donahue's (2007) assertion that "learning to teach is about negotiating identities, finding out who one is in the classroom" (p. 75). As Duncan's performing in class is an extension of who he is, it would be interesting to go back to his understanding of coming out to understand the relationship between Duncan, his performing in class, and his identity as a teacher.

Let's say socially, the coming out and let's say ... historically the term comes from gays coming out of the closet, you know English so I do not need to translate it, but the process that involves coming out for one of gay is very complex because it is in some way or another embracing who you really are and show it socially, so people will either buy or reject it but it's just about you telling the world who you are [...] But now that I am sure of what I am, I like to show a little and share those perspectives from music to opinions, thoughts that in some way or another allow me to share who I am, so that my students can show as well who they are and in some way or another there is no forced environment but that we are the real individuals that we are in ... pursuing the objectives we have, I would like to believe that my discourse is coherent with my ... behaviour and is coherent with my thought process so I would like to think that I am coherent and that makes me a better person and a better teacher for my students by all means.

Duncan's identity is rooted in the concept of self-understanding. This means that, in narrating himself, Duncan is framing his identity within the contexts where he is. Moreover, as a result of such interpretation and re-interpretation of his experiences, his understanding of experiences alters and 
adds tension to any known notion or conceptual framework of identity as one's development cannot be explained just by conceptualizing it from a norm, but from the personal experiences that situate the queer in him. Aligned to this, it might seem important to pinpoint that as teachers get opportunities in which they can develop their ideas about themselves, it is crucial to their performance in the class (Bullough, 2008) to be able to understand how personal theories, attitudes, and beliefs that teachers have about themselves are developed throughout their teaching careers.

In the analysis above, we see Duncan's persona as an important element in reconfiguring notions of how professional identity is developed. As teachers' professional identities change due to different experiences during their careers, we find it meaningful to build deeper knowledge and understanding of the pedagogical interventions that are committed to contesting heteronormativity. Therefore, although pedagogical interventions narrated here might not be intended to intentionally address constraining systems of thought and grids of intelligibility pertaining to the privileging of heterosexuality, we believe they do have the potential to serve "as an imaginary site for multiplying alternative forms of identifications and pleasures not so closely affixed to - but nonetheless transforming - what one imagines their identity imperatives to be" (Britzman, 1998, p. 85).

Thus, the following excerpt, we think, resonates with our commitment to exploring conditions of possibility for imagining a social self and forms of identification that are not fixed by colonial notions of self by advocating for a pedagogy that works as a political mechanism to decolonize gender and identity constructed in modern territories.

This work is not about pleasing, but it has to do with my philosophy of life: kindness and love and understanding. Let me explain, the way I have found to feel better about who I am is by accepting the fact that I work with a group of people, not only students and teachers but ....and when you have to work with other people you need to learn basic social skills that allow you to wear the other shoes [...] of course, what I really appreciate about being a teacher is that I have been given the gift to see the inner child of everybody and to see how beautiful they are, they are all different but everybody has something nice to bring and when that pops up everything works better but where there is stress when there is miscommunication, where there is... this atmosphere... then I think the best way to work towards better understanding and better constructions of common territories is to get to know each other to work towards it and to implement real actions.

Duncan's narrative positions the importance of working with the other, to understand the other if common territories are to be built. We believe that this represents a very important decolonial lens since it becomes an epistemic weapon to dismantle any hierarchy that privileges Western cosmology over non-Western knowledge cosmologies (Mignolo, 2000). With this, we mean to say that, in the field and in all the modern world, there have been established dominant conceptions of who the other is, and how to coexist and inhabit the territory. However, Duncan breaks down this assumption by sustaining that territories come from the power of enunciation where his identity emerges as "a more solid source of meaning because identity involves a process of self-construction and individualization" (Mingren \& Shiquan, 2018, p. 92) that cannot be detached from our self-driven interest in acknowledging the other and being acknowledged.

\section{Conclusions}

This study had no other purpose than installing the decolonial spirit in matters of gender in relation to ELT. As such a stance assumes a social justice orientation, the voices we heard and learned from in this study stand for what we consider to be the most liberatory mechanism for applying epistemological/ cognitive justice (De Sousa Santos, 2009) in matters of gender in the ELT field. As a result, what Duncan and Lea shared with us paves the way to produce, from a position of subalternity within the geopolitical logic of knowledge, a valid epistemological contribution to reproduce and construct knowledge within and from a different alternative project. 
We consider identity to be pivotal. Most of what is said in the ELT field barely questions the mental categories of identity due to our exposure to society (Warner, 1999) and as such, those who are in the process of becoming EFL teachers and, even those who are already teachers of English barely have had the chance to challenge who they are as beings and professionals. Although it might be certain that developing a professional identity is essential to become a successful teacher (Olsen, 2010), teacher identity cannot be restricted just to the professional dimension of knowing how to do a job instrumentally. In fact, teacher identity is shaped by personal narratives (e.g. Atkinson, 2004; Cohen, 2008).

Two principal conclusions can be drawn. First, as seen in Lea's narrative, identity is a personal construction that, although framed by social and external discourses, is highly fragmented due to the experiences identity is composed of, where identity cannot be defined by categories as it is situated in and from the individual's experience. Second, language teacher identity is the result of the individual's own performing in context as seen in Lea and Duncan's narratives.

Therefore, colonial patterns of power, that are commonly related to identity as an ontological category, foster an intersubjective relation framed by modernity. Nevertheless, as experience discloses and disrupts the residual colonial architecture formed from socio-historical configurations of being, queer language teacher identity cannot therefore just be an expression of coloniality of gender, as ontology is a concept refined in a de-colonial/modern context where queer performances and identitarian categories are interwoven.

The queer identities documented in this study emerged as personal construction of the self in the context of a socially constructed activity like teaching English. For Example, Duncan and Lea put down heteronormative and oppressing notions imposed on the self by displaying self-awareness, agency, and freedom from an ethical position as queer teachers. This is quite important as such features intentionally subvert the colonial contemporary reality they are facing as professionals. Therefore, we consider that as dimensions of coloniality (being/knowledge/ power) can indeed interplay with one another in the EFL classroom, narratives reported here not only pose conflicting notions of academic colonialism present in Colombian ELT, but they also present knowledge of 'subaltern professionals' as relevant for the ELT community. Regarding this, Duncan and Lea both made evident that "language pedagogy has an ethical goal that goes into the construction of intersubjective meanings that help us both to understand ourselves and others in the interest of better societies" (Granados-Brán, 2018, p. 175) and as such, who you are has a stake in what you do and how you see and relate with others (Kemmis et al, 2014). Consequently, language teaching goes beyond a set of linguistic items, methods or methodologies to be mastered.

These conclusions, far from being a final understanding of the experiences examined, are local and situated knowledges which unsettle the coloniality of power and its constitutive matrix (Quijano, 2000b, p. 533). Conclusively, the hidden but hegemonic Euro-American-centric values that have influenced and shaped models of identity and of being for queer teachers of English still need to be contested and therefore, much more research is needed to voice and listen to those who have been dispossessed, silenced, and rejected by modern logic.

\section{References}

Atkinson, D. (2004). Theorising how student teachers form their identities in initial education. British Educational Research Journal, 30, 3, 379-94.

Barkhuizen, G. (2011). Narrative Knowledging in TESOL. TESOL Quarterly, 45, 391-414. doi:10.5054/ tq. 2011.261888

Battiste, M. (2013). Decolonizing education: Nourishing the learning spirit. Purich Publishing.

Borsani, M. E. (2014). Reconstrucciones metodológicas y/o metodologías a posteriori. Astrolabio, 13, 146-168

Britzman, D. (1998). Lost subjects, contested objects. Albany: State University of New York Press.

Bruner, J. (1987). Life as narrative. Social Research, 54 (1), 11-32. 
Bullough, R. V. (2008). Counternarratives: Studies of teacher education and becoming and being a teacher. State University of New York Press.

Butler, J. (1990). Gender Trouble: Feminism and the Subversion of Identity. Routledge.

Butler, J. (2004). Undoing Gender. Routledge.

Clandinin, D. J., Cave, M. T., \& Berendonk, C. (2017). Narrative inquiry: a relational research methodology for medical education. Medical Education, 51(1), 89-96. https://doi-org.ezproxy.javeriana.edu. co/10.1111/medu.13136

Cohen, J.L. (2008). 'That's not treating you as a professional': Teachers constructing complex professional identities through talk. Teachers and Teaching: Theory and Practice 14(2), 79-93.

Connell, R. (2009). A thousand miles from kind: men, masculinities, and modern institutions. The Journal of Men's Studies, 16(3), 237-253.

Dewey, J. (1938). Experience and education. Collier Books.

De Sousa Santos, B. (2009). Una epistemología del sur. Clacso Ediciones.

Domínguez, E. \& Herrera, J. (2011). La investigación narrativa en Psicología: Definición y funciones. Revista Psicología desde El Caribe, 30(3), 620-641.

Donahue, D. M. (2007). Rethinking silence as support: Normalizing lesbian and gay teacher identities through models and conversations in student teaching. Journal of Gay and Lesbian Issues in Education, 4(4), 73-95. https://doi.org/10.1300/J367v04n04_06.

Du Bois, W. E. B. (1999). The soul of back folk. In H. L. Gates Jr \& T. Hume (Eds.), Authoritative text. Contexts, criticisms. W.W. Norton \& Co.

Elliott, J. (2005). Using narrative in social research: Qualitative and quantitative approaches. Sage

Escobar, A. (2010). Afterword. In W. Mignolo \& A. Escobar (Eds.), Globalization and the decolonial option (pp. 391-399). Routledge.

Fajardo Castañeda, J. (2014). Learning to Teach and Professional Identity: Images of Personal and Professional Recognition. Profile: Issues in Teachers 'Professional Development, 16(2), 49-65. https://doi. org/10.15446/profile.v16n2.38075

Ferfolja, T. (2009). Stories so far: An overview of the research on lesbian teachers. Sexualities, 12(3), 378-396.

Gates, G. J. (2011). How Many People are Lesbian, Gay, Bisexual and Transgender? UCLA: The Williams Institute. https://escholarship.org/uc/item/09h684x2
Gee, J.P. (2000). Identity as an analytic lens for research in education. Review of Research in Education, 25, 99-125.

Granados-Brán, C. (2018). Revisiting the Need for Critical Research in Undergraduate Colombian English Language Teaching. HOW Journal, 25(1), 174-193. https://doi.org/10.19183/how.25.1.355

Gray, J. (2016). Language and non-normative sexual identities. In S. Preece (Ed.), The Routledge handbook of language and identity (pp. 225-240). Routledge.

Griffin, P. (1992). From hiding out to coming out: empowering lesbian and gay educators, in Coming Out of the Classroom Closet: Gay and Lesbian Students, Teachers, and Curricula, ed. K. M. Harbeck, Harrington Park Press, New York, pp. 167-196.

Grosfoguel, R. (2005). The Implications of Subaltern Epistemologies for Global Capitalism: Transmodernity, Border Thinking and Global Coloniality. Ed. William I. Robinson and Richard Applebaum. Critical Globalization Studies. Routledge.

Grosfoguel, R. (2008). Transmodernity, border thinking and global coloniality. Eurozone: Decolonizing political economy and postcolonial studies.

Haber, A. (2011). Nometodología Payanesa: Notas de metodología indisciplinada (con comentarios de Henry Tantalean, Francisco Gil García y Dante Angelo). Revista Chilena de Antropología, (23). https:// doi.org/10.5354/0719-1472.2011.15564

Hanson, J., Paulsen, M., \& Pascarella, E. (2016). Understanding graduate school aspirations: the effect of good teaching practices. Higher Education (00181560), 71(5), 735-752. https://doi-org. ezproxy.javeriana.edu.co/10.1007/s10734-0159934-2

Hooker, S. D. (2010). Closeted or out? Gay and lesbian educators reveal their experiences about their sexual identities in $\mathrm{K}-12$ schools (Doctoral dissertation). Retrieved from OAIster at http://oaister.worldcat. org/. University of Cincinnati, Cincinnati, $\mathrm{OH}$.

Hooks, (1990). Yearning: Race, Gender and Cultural Politics. South End.

Kemmis, S., Wilkinson, J., Edwards-Groves, C., Hardy, I., Grootenboer, P. y Bristol, L. (2014). Changing practices, changing education. Springer Science \& Business Media.

Kissen, R. (1996). The last closet: The real lives of lesbian and gay teachers. Heinemann. 
Kumaravadivelu, B. (2012). Language teacher education for a global society. Routledge.

Lander, R. (2018). Queer English language teacher identity: A narrative exploration in Colombia. Profile: Issues in Teachers' Professional Development, 20(1), 89-101. https://doi.org/10.15446/profle.v20n1.63658.

Litosseliti, L. (2006). Gender and language: Theory and practice. Hodder Arnold.

Lugones, M. (2003). Heterosexualism and the colonial/ modern gender system. Hypatia 22(1),186-209.

Lugones, M. (2008). The Coloniality of Gender. Worlds \& Knowledges Otherwise. Spring.

Lugones, M. (2010). Toward a decolonial feminism. Hypatia, 25(4), 742-759

Maldonado-Torres, N. (2007). On the Coloniality of Being. Cultural Studies, 21(2/3), 240-270. https://doi-org. ezproxy.javeriana.edu.co/10.1080/09502380601162548

Maldonado-Torres, N. (2011). Thinking through the decolonial turn: Post-continental interventions in theory, philosophy, and critique-An introduction. Transmodernity: Journal of Peripheral Cultural Production of the Luso-Hispanic World, 1(2) 240-270.

Maldonado-Torres, N. (2017). The Decolonial Turn. In J. Poblete (ed.), New Approaches to Latin American Studies: Culture and Power. Routledge, 111-127.

Mayer, M. \& Wodak, R. (2009). Critical discourse analysis: history agenda theory, and methodology. In R. Wodak \& M. Mayer (Eds.), Methods of critical discourse analysis (pp. 1-34). SAGE.

Meijer, P. C., de Graaf, G. \& Meirink, J. A. (2011). Key experiences in student teachers' development. Teachers and Teaching: Theory and Practice, 17(1), 115-129.

Mendoza, B. (2016). Coloniality of Gender and Power: From Postcoloniality to Decoloniality. In L. Disch, M. Hawkesworth. The Oxford Handbook of Feminist Theory (pp. 100-121). Oxford University Press.

Mignolo, W. (2000). Local histories/global designs: Coloniality, subaltern knowledges and border thinking. Princeton University Press.

Mignolo, W. (2011). Historias locales/Diseños globales. Colonialidad, conocimientos subalternos y pensamiento fronterizo. Ediciones Akal.

Mignolo, W. \& Walsh, K. (2018). On Coloniality. Duke University Press.

Miles \& Huberman. (1994). Qualitative Data Analysis. Thousand Oaks, Sage.
Mingren, Z., \& Shiquan, F. (2018). Rural Teacher Identity and Influencing Factors in Western China. Chinese Education \& Society, 51(2), 91-102. https://doi-org.ezproxy. javeriana.edu.co/10.1080/10611932.2018.1433410

Mockler, N. (2011). Beyond 'what works': Understanding teacher identity as a practical and political tool. Teachers and Teaching: Theory and Practice, 17(5), 517-528. https://doi.org/10.1080/13540602.2011.602059

Mojica, C., \& Castañeda-Peña, H. (2017). A Learning Experience of the Gender Perspective in English Teaching Contexts. Profile: Issues in Teachers' Professional Development, 19(1), 139-153. https:// doi.org/10.15446/profile.v19n1.56209

Nash, C.J. (2010). Queer conversations: old-time lesbians, transmen and the politics of queer research. In Browne, K. and Nash, C.J. (eds) Queer Methods and Methodologies: Intersecting Queer Theories and Social Science Research, (pp. 129-42). Ashgate.

Olsen, B. (2010). Teaching for success: Developing your teacher identity in today's classroom. Paradigm.

Ortiz Ocaña, A. \& Arias López, M. I. (2019). Hacer decolonial: desobedecer a la metodología de investigación. Hallazgos, 16(31), 147-166. https://doi. org/10.15332/s1794-3841.2019.0031.06

Palmer, P. J. (2007). The Courage to Teach: Exploring the Inner Landscape of a Teacher's Life. 10th anniversary edn, Jossey-Bass, San Francisco.

Patel, L. (2019). Decolonizing Educational Research. From ownership to answerability. Routledge. University of Massachusetts.

Pennycook, A. (1998). English and the discourses of colonialism. Routledge.

Quijano, A. (1992). Colonialidad y modernidad-racionalidad. En H. Bonilla (Ed.), Los conquistados: 1492 y la población indígena de las Américas (pp. 437-447). Tercer Mundo Editores.

Quijano, A. (2000a). Coloniality of power: Eurocentrism and Latin America. Nepantla: Views from the South, 1(3), 533-583.

Quijano, A. (2000b).Colonialidad del Poder y Clasificación Social. Festschrift for Immanuel Wallerstein, part I. Journal of World Systems Research, 6(2).

Rodríguez, A. (2016). El giro decolonial en el siglo XxI. Ensayos Pedagógicos, 11(2), 133-158.

Sfard, A. \& Prusak, A. (2005). Telling Identities: In Search of an Analytic Tool for Investigating Learning as a 
Culturally Shaped Activity. Educational Researcher, 34(4), 14-22.

Sharma, N., \& Agmad Mir, S. (2019). Decolonizing education: Re-schooling in India. Sinéctica, (52), 1-10. https://doi-org.ezproxy.javeriana.edu.co/10.31391/ S2007-7033(2019)0052-007

Spargo, T. (2004). Foucault y la teoría queer. Gedisa Editorial. Sumara, D., \& Davis, B. (1999). Interrupting heteronormativity: Toward a queer curriculum theory. Curriculum Inquiry, 29(2), 191-208

Taylor, C. (1989). Sources of the Self. The Making of the Modern Identity. Cambridge: Cambridge University Press.

Thompson, S. A. (2004). Operation "special": Interrogating the queer production of everyday myths in special education. In J. McNinch \& M. Cronin (Eds.), I could not speak my heart: Education and social justice for gay and lesbian youth (pp. 273-388). University of Regina Press.
Trent, J. (2013). From learner to teacher: practice, language, and identity in a teaching practicum. Asia-Pacific Journal of Teacher Education, 41(4), 426-440. https://doi-org.ezproxy.javeriana.edu. co/10.1080/1359866X.2013.838621

Walsh, C. (2009). Interculturalidad crítica y pedagogía de-colonial: apuestas (des)de el in-surgir, re-existir y re-vivir. En V. M. Candau (Ed.). Educação intercultural na América Latina: entre concepções, tensões e propostas (pp. 14-53). 7 letras.

Watson, C. (2006). Narratives of practice and the construction of identity in teaching. Teachers and Teaching: Theory and Practice 12(5), 509-26.

Warner, M. (1999). The trouble with normal: Sex, politics, and the ethics of queer life. Harvard University Press.

Wilchins, R. (2004). Queer Theory, Gender Theory: An Instant Primer. Alyson Books. 
